\title{
DEVELOPING A MODEL OF COGNITIVE PSYCHOTHERAPY BASED ON INDONESIA ISLAMIC' VALUES ON TERRORIST
}

\author{
Arman Marwing \\ Faculty of Ushuluddin Adab and Dakwah IAIN Tulungagung \\ Center for Sufism Research and Therapy (CSRT IAIN Tulungagung) \\ e-mail:marwingarman@gmail.com
}

Diterima: 02 Februari 2018

Direvisi : 04 April 2018

Diterbitkan: 30 Juni 2018

\begin{abstract}
High rate of recidivism on terrorists indicates the weakness of deradicalization programs. This study aims to offer a solution through development of a cognitive psychotherapy which based on Indonesia Islam values. The integration among Islam, culture and psychotherapy is able to belp the terrorists to identify and restructure their cognitive that causes their emotion and destructive behaviors. This qualitivative study mixes between literature and phenomenology approaches. This study found that there are conflicting differences between the views of the terrorists and ijtihad of Indonesia Ulama regarding khilafah, jihad and takfiri concepts. In Addition, the model of cognitive psychotherapy based on Indonesian Islamic values was developed by content analysis and its implementation followed several systematic procedures such as anamnesis, assessment, diagnosis, intervention, result of intervention, follow up. Embracing humantic approach and collaborative Empiricism procesures enable the therapy effectively internalize Indonesia Islamic values such as Tasamub (tolerance), Tawasuth (moderate), Tawazun (balanced), 'Adalah (Justice) and Ukbuwah (Brotherbood), which includes ukbuwah Islamiyah (other Muslims), Ukhuwah Wathoniyah (fellow citizens), Ukhuwah basyariah (fellow citizens) for the terrorists. These values could be intentionally internalized by terrorist itself and threfore it would be effective model to modify terrorists' destructive thought schemas (cognitive), emotion and behavior to be adaptive.
\end{abstract}

Keywords : Psychotherapy, Cognitive, Islam, Terrorist



Residivisme pelaku terorisme yang tinggi menunjukkan kelemahan program deradikalisasi. Penelitian ini bertujuan untuk menawarkan konstruksi model psikoterapi kognitif berbasis nilai Islam Indonesia sebagai salah satu solusi. Sebuah integrasi antara Islam, budaya dan psikoterapi dalam membantu pelaku terorisme mengidentifikasi dan merestrukturisasi kognitif yang menjadi penyebab emosi dan perilaku destruktif. Metode yang digunakan adalah penelitian kualitatif dengan menggunakan perpaduan studi literatur dan fenomenologi. Hasil penelitian menemukan adanya perbedaan pandangan yang kontradiktif antara pelaku terorisme dan ijtihad Ulama Nusantara mengenai konsep khilafah, Jihad dan Takfiri. Selain itu model psikoterapi kognitif berbasis nilai Islam Indonesia dihasilkan melalui pengujian isi serta menerapkan beberapa prosedur atau tahapan yang sistematis yaitu anamnesis, pemeriksaan, diagnosis, kontruksi model terapi, hasil intervensi dan tindak lanjut. Melalui pendekatan humanis dan prosedur collaborative Empiricism terapi ini memungkinkan nilai-nilai Islam Indonesia yang mengedepankan Tasamub (toleransi), Tawasuth (moderat), Tawazun (berimbang), 'Adalah (Keadilan), dan Ukbuwah (Persaudaraan) yang meliputi ukbuwab Islamiyah (sesama Islam), Ukhuwah Wathoniyah (Sesama warga negara), Ukhuwah basyariah (sesama umat manusia) dapat terinternalisasi dengan kesadaran dan tanggung jawab dari pelaku teroris itu sendiri, serta dapat efektif mengubah skema berpikir,emosi dan perilaku teroris menjadi adaptif.

Kata Kunci : Psikoterapi, kognitif, Islam, Terorisme 


\section{Background}

The de-radicalization programme of terrorist in Indonesia is a strategic issue that needs to be addressed. The widespread problem of terrorist recidivism is a clear indicator of the ineffectiveness of the program. Data of National Agency for the Fight against Terrorism (BNPT) in 2013 shows that approximately 25 of the 300 terrorists which was released from prison have returned to act terrorism, and the recidivism rate for terrorist acts has varied by $15 \% .47$ cases discovered in Indonesia . ${ }^{1}$ The evidence of involvement of two terrorism recidivists in terrorism attacks and suicides in Jakarta in early 2016 is clearly evidence to show ineffectiveness of deradicalization programs in Indonesian prisons.

Futhermore, many de-radicalization programs particularly in correctional institution such as conflict management training, puppet shows and pancasila clinic can not secure public safety from their reccurent destructive behavior. Government-centric policy and disregard of understanding and personal needs of the terrorist result monologue, directional (counseling), unemotional practices in therapy. These factors are accused of causes why these programme achieve not the goals.

Terrorist prisoners is prone to be sceptical since the program does not represents their needs. They apply calculation for profits and loss before determining to involve the deradicalisation program. For example, what are the benefits of the program for me? If it hurts me, why should I follow the program?

Because of regarding Indonesian government is a thagut, terrorists tend to overlook de-radicalization program, expect that the programme can represent their needs. As a measure to open their mental block, a

\footnotetext{
${ }^{1}$ Noor huda Ismail \& Susan Sim, Predicting terrorist recidivism in Indonesia's prisons. The Brooking Press , 2016, january 28. Para.3
}

cognitive therapy based on Indonesia Islam value is proposed as an ideal model of rehabilitation or deradicalization of terrorists because it uses non-directive approach and directly affects the personality aspects of each individual, regardless of their main problems to rasionalize their destructive actions.

De La Corte's findings indicate that several common psychological attributes of terrorists are a lack of victim empathy, dogmatism, an ideological mentality or a simplistic and utopian view on world. ${ }^{2}$. According to Storr, with these beliefs and ways of thinking, terrorists turn into aggressive psychopath people who lose of consciousness, , cruel, aggressive, sadistic and ruthless. They have no fear of death including death for himself as well as the death of others. ${ }^{3}$

According to Aroon T. Beck, a pioneer of cognitive psychology, finding of De La Corte on terrorist characteristics could be regarded as a cause and a consequence of the cognitive distortions of the perpetrators of terrorism. Cognitive distortions refer to errors or errors of thought that affect a person's emotions, feelings and behavior. The existence of cognitive distortions leads to a rationalization of the behavior which tends to lead to the crime, whereby these actions is dangerous, not only for the perpetrators of terrorism but also for other innocents. ${ }^{4}$

Some cognitive distortions of terrorists are overgeneralization in which they perceive their enemies 's sins or mistakes of individuals or groups can spread through the population. Terrorists also manifest a dichotomous thought, a term refers to regarding a person either totally good or bad. They also shows a

${ }^{2}$ L., De la Corte, La logica del terorismo.( Madrid : Alianza, 2006), p.264 .

3 Anthony Storr, The threat of man buman aggresion. (London: The Penguin Press, 1968), p. 45.

4 Aaron T. Beck dan Marjorie E. Weishaar dalam Raymond J. Cosini \& Danny wedding, Current Psychotherapies, Fourth Edition (Illinois: FE Peacock, 1989), p. 285. 
vision in tunnel, a belief that participation in "sacred missions" such as jihad must be designed in such as way to destroy, harm, damage their target, even thougth they have to sacrifice their life for the mission. For example, suicide bombers, as well as the suicide bombers in Solo City Police Headquarters, on July 2016, were happier when they died as martyrs because of beliefs on good rewards for their acts of terrorism.

Based on the cognitive complexity underlying thoughts and acts of terrorism, cognitive psychotherapy is responsible for restructuring the cognitive distortions which have changed the perceptions of perpetrators of reality. a cognitive logic, as result of such psychotherapy will produce a healthier and adaptive response such as a better mood and avoidance of future acts of terrorism.

In considering that dogmatic dimensions of the religious behavior of terrorism have pivotal role on terrorist behaviors, the development of a cognitive psychotherapy model based on the Indonesian Islamic values such as tawassuth (moderate), tasamub (tolerant), tawazun (balanced) and i'tidal ( perpendicular), and position of Indonesia Islam as a rahmatan lil alamin (mercy for the universe) proposes then.

The infiltration of Indonesian Islamic values as a interrelated Islam and Indonesian cultural wisdom on psychotherapy context enable cognitive psychotherapists to easily understand basic assumptions and values Islam as mercy for the universe and to determine their positioning as agents of such Islam values by providing such treatment for terrorism detainees. At the same time, this responds to the ethical dilemma among psychotherapists who doubt including dogmatic assumptions in their psychotherapy as well as it copes with their inferiority because of limitation of their religious understanding.

\section{Causes of terrorism: individual psychological levels, group identity and cognitive.}

Most psychological explanations of the causes of terrorism are linked to explanations at the individual level. For example, the frustration-aggression hypothesis that the perpetrators opted for terror because they were frustrated that their political goals would never be achieved. This theory is considered mechanistic since the similar frustrating conditions do not automatically encourage people to commit an act of terrorism. ${ }^{5}$

Individual explanations of the personality aspects of terrorists state that they are individuals with psychopathological or disruptive personalities such as impulsive aggression. Later, many studies have contrasted the general nature of terrorists with aspects of the personality. Milla stated that terrorists did not always have psychological predispositions leading to terrorist behavior, such as frustrating experiences and traumatic experience. However these perpetrators were individuals who subordinated their personal identity to a group identity based on religious groups. Strenghtening of Identity occurs when they perceived threat is directed to their group.

From this point forward, the perspective of social identity explains that a person's behavior can be encouraged and influenced by his or her belonging to the group. Terrorism is a group phenomenon, where individuals decide and take theoretical measures guided by the group's decisions and the objectives to be achieved by the group. Terrorists in terrorist organizations have different positions and hierarchical roles, ranging from sponsors, executives, executive committees, middle

5 Leonard Berkowitz, “ Frustation -Aggression Hypothesis: Examination and Reformulation ", Psychological Bulletin, 106, 1989, p. 59.

${ }^{6}$ Mirra Noor Milla \& Faturochman, " Pembentukan identitas mujahid global pada terpidana kasus terorisme di Indonesia", Jurnal Psikologi Indonesia, Vol. VI, No.2, h. 82. 
managers and followers, who also play different roles. These different positions and roles emphasize the subordination of personal identity to achieve the group's common goals. ${ }^{7}$

The incorporation of individual identity into the identity of this group has its own consequences. Victoroff explains that the strength of the group, including ideological indoctrination, repeated training, pressure from other group members, was supposed to influence the intention to commit violence among members of group either for those who have predisposition to violent behavior or not have such predisposition.

The incorporation of individual identities into these groups provides a very important justification for their actions with the loss of sense of responsibility. The impact of group polarization encourages individuals to commit high-risk actions. ${ }^{8}$

This study focuses on the cognitive aspects of terrorists as resut of intensive indoctrination processes. The cognitive approach emphasizes a strong emphasis on the role of cognitive capacity and cognitive style of individuals in learning and respecting rules, anticipating the results of actions, formulating reasonable conclusions, or calculating accurately result. ${ }^{9}$

There is number of evidence prove that violent behavior is influenced by cognitive ability and style. ${ }^{10}$ The cognitive style, for example, how the way of consistence thinking of indivdual in processing information causes individual aggressive behaviour. Individuals who choose to be terrorist followers or even

${ }^{7}$ Jeff Victoroff, " The mind of the terrorist: A review and critique of psychological approaches ", Journal of conflict resolution, 49, 2005, p. 3.

${ }^{8} \mathrm{~J}$ Victoroff , "The mind of the terrorist: A review and critique of psychological approaches "p. 6

${ }^{9}$ Muriel Deutsch Lezak, Neuropsychological assessment 3rd ed (New York : Oxford University Press , 1995), h. 213.

${ }^{10}$ Enest T Bryant; Monte L Scott; Christopher D. Tori

\& Charles J. Golden, "Neuropsychological deficits, learning disability, and violent behavior" , Journal of Consulting and Clinical Psychology 52, 1984 ,323, p. 4. leaders of terrorist groups are associated with individuals which having biased, prejudiced, or tendentious cognitive style. Cognitive style would change when indiviual identities was subordinated to group identity. Strict boundaries are applied among members of theradical group.They identifies themselves as in-group because they shared the similar motivation "to perform the Jihad according to the path of Allah" by way of violence. In contrast, they regards the other groups as "out group" or enemies or enemies of Allah. These indications indicate effects of cognitive distortions to reinforce negative suggestions or bad emotions about themselves, as well as unreal things that seem rational have adverse effects for them particularly they are prone to suffer bad feeling ${ }^{11}$.

Some types of cognitive distortions include: a) Polarisation (dichotomous thinking); (b) Overgeneralization; (c) selective abstraction (Tunnel Vision); (d) disqualifying the positive; (e) Mental reading ( arbitrary inference); (f) maximization and Minimization; (g) emotional reasoning; (h/) Imperative; (i) Labeling), (J) Personalization. ${ }^{12}$

Islamic Radicalism, Cognitive Distortion of Terrorists and Cognitive Psychotherapy

The causal relationship of radicalism and cognitive distortion is inseparable. referring to Ellies' conception that cognitive distortion is a reality of human life that is formed from illogical experiences and learning processes, obtained from parents, family, society and culture, cognitive distortions among members of terrorist groups then are formed from processes of radicalization, illogical learning

\footnotetext{
11 Beck dalam David D Burns, Terapi kognitif: pendekatan baru bagi penanganan depresi (Jakarta : Erlangga, 1988), p.23

12 David D Burns, Terapi kognitif: pendekatan baru bagi penanganan depresi, p. 30-31.
} 
process, systematically obtained from the organization. ${ }^{13}$

Such learning process is illogical ways because it does not provide an opportunity to encourage self-reflection and criticism of the group members.Radical groups believe that, Islam ideologically regulates not only religion aspects, but also the political system, therefore , every modern Muslims, in their perspective, must return to purely religious roots and unite all of moslems politically ${ }^{14}$

In a terrorism organization with Islamic ideology, radicalism is a process in which its members gradually adopt religious and political ideologies that conflict with Western democratic values and legitimize acts of terrorism as engines of social change. $^{15}$

Shemas of cognitive distortions is constructed through the process of radicalism, and even have a domino effect on human emotions and behaviors. Even Ellis states that thoughts, emotions, and behaviors are triadic relationships, as illustrated by the fact that when someone feel emotion, he also thinks and acts; when someone acts, he thinks and as well as he feels emotion; and when someone thinks, he also feels emotion and acts. ${ }^{16}$ Terrorists certainly experience these conditions as well therefore their cognitive distortion provokes irrational violent behavior because it iinvolves emotion as explosive power. This whole process is triadically illustrated in the process of radicalization of Silber and Bhatt.

They argue that the radicalization processes follow four stages : (1) pre-

13 Ellies dalam Rickey L George; Therese Stridde Christiani, Theory, Methods \& Processes of Counseling and Psychotherapy (Englewood Cliffs, N.J.: Prentice-Hall, 1981), p. 89

14 Sheri Berman. Islamism, Revolution, and Civil Society, Perspectives on Politics, 1, American Political Science Association, 2003, p. 18

${ }^{15}$ Mitchell D. Silber and Arvin Bhatt, Radicalisation in the West : The Homegrown Threat : (The New York City: Police Department, 2007) p.16

${ }^{16}$ Albert Ellis, Rational-Emotive Theory dalam A. Burton (Ed.), Operational Theories of Personality (New York : Brunner/ Mazel, 1974). p. 313 radicalization, (2) self-identification, (3) indoctrination, (4) jihadization. Preradicalization is the initial phase, where the individuals do not recognize and embrace radical ideology as their personal ideology. Silber and Bhatt indicate that the majority of people in this phase are ordinary people who have a job and a normal life and few of them have a criminal record. ${ }^{17}$

This likewise confirms the lowcorrelation between terrorism behavior and personality or psychological profiles such as psychopaths and disruptive or sadistic personalities. The psychiatrist Marc Sageman has identified 172 people as "Global Salafi Mujahedin", such as expatriate leaders of the Egyptian expatriate Islamic group (EIG), Egyptian Islamic Jihad (EIJ), Jemaah Islamiyah, Moro Islamic Liberation Front, Algerian Groupe Salafiste pour la predication et le Combat (GSPC), and the Al Qaeda group. As a result, out of 61 leaders with fragmentary data during their childhood, only 4 had a history of encouraging behavioral disturbances, even in only one case, namely the case of habib Zacarias Moussaoui's who have traumatic condition in his childhood.

In terms of personality, apart from solitary personalities, most descriptions of their personality are neutral and positive. In terms of their criminal record, only a quarter of those involved in minor offenses. The detailed biographical follow-up of 10 cases did not reveal samples with pathological narcissism or paranoid personality disorder. . ${ }^{19}$ Therefore, explanations at the individual level related to personality characteristics, history of crimes committed during childhood or certain

\footnotetext{
${ }^{17}$ Mitchell D. Silber and Arvin Bhatt, Radicalisation in the West : The Homegrown Threat : (The New York City: Police Department, 2007) p.16

18 Marc Sageman, Understanding terror networks (Philadelphia: University of Pennsylvania Press, 2004), p.286.

19 Marc Sageman, Understanding terror networks, p.287.
} 
psychological disorders such as paranoid and pathological narcissism urgently require an evaluation.

The next stage of radicalization is selfidentification where individuals are influenced by both internal and external factors. Individuals began to study religious doctrines, especially those proposed in radical religious organizations. At the individual stage, they begin to abandon their old identities and associate with people who have similar tenet and adopt new ideologies from referral organizations. Pursuing religious identity which indicate stage of identity crisis can be regarded as the catalyst for people to leave their beliefs and accept a recent views of life.

The identity crisis as a catalyst is more likely occur in a specific developmental phase, especially in adolescence. Identity research encourages adolescents to determine their enemy or their ideal figure who guide them achieving their final identity. ${ }^{20}$ Youth who fail to consolidate their identity tend to have low self-esteem and follow their role model's guidances particularly commiting terrorism acts.

There is a great deal of demographic information about the participation of adolescents or youth in terrorist groups, such as Hassan's study on Islamic Jihad members, whose members are on average 18 to 38 years old. ${ }^{21}$ particularly, studies of Salafi Muslim terrorists from Saudi Arabia, Egypt, France, Algeria, Morocco and Indonesia show that the average age of members is 25.69 years. ${ }^{22}$

In the process of self-identification, members act actively, seeking relationships and associations with others with a similar understanding. They adopted a radical doctrine

20 Elizabeth B. Hurlock, Psikologi Perkembangan. Suatu pendekatan sepanjang rentang kehidupan, Edisi 5. (Jakarta : Erlangga, 1980), p. 209

21 Nasra Hassan, An arsenal of believers : Talking to the " human bombs", The New Yorker,77, 2001, h.36.

22 Marc Sageman, Understanding terror networks, p.289. of diversity through the participation of recitations and communities and showed changes in mentality and behavior. On this stage, schemas of thought that produce cognitive distortions emerge primarily related to truth claim for their religious ideas and views. In contrast, they claim beliefs of outside groups are false. These dichotomous thoughts isolate them emotionally and decide to stay away from their old lives.

Even though the schema of mind that encourage cognitive distortions appeared, it is likewise strengthened during the indoctrination phase. This phase is illustrated by the progressive individual development to strength religious beliefs. The radicalism perspective of radical Islamic groups is extended and reinforced by doctrinal patterns which are intensively internalized through small groups called usrah or halaqoh. In this phase, according to Sillber and Bhatt, the ideology of jihad has been adopted and concluded. They also accepts the belief to support their ideology by commiting violence "Jihad" acts.

At this stage, the member of radical group accept a political-religious perspective that justifies, ratifies, encourages and supports violence against others which is considered as "kufr", non-Islamic entities, including Western civilization, its people, its allies or any other considered having different views. ${ }^{23}$

This stage will end with jihadization, a phase in which each member of the group accepts their individual obligations to participate in "jihad" and identifies themselves as holy soldiers or mujahideen. In the end, the group will begin the operational planning of an act of terrorism. However this study elaborate deeply at the stage of indoctrination where cognitive distortions of the group members are reinforced and cause other cognitive distortions. The cognitive distortions at this

\footnotetext{
${ }^{23}$ Mitchell D. Silber and Arvin Bhatt, Radicalisation in the West : The Homegrown Threat (New York : The New York City Police Department, 2007), p.311
} 
phase can be identified and illustrated in the following table.

Table 1. Forms of cognitive distortion of terrorists

\begin{tabular}{|c|c|c|}
\hline $\begin{array}{l}\mathrm{N} \\
\mathbf{o}\end{array}$ & $\begin{array}{l}\text { Cognitve } \\
\text { distortions' } \\
\text { forms }\end{array}$ & Automatic thoughts \\
\hline 1. & Polarization & $\begin{array}{l}\text { West against Islam, } \\
\text { Kafir against Muslim. } \\
\text { We (Minna) against them } \\
\text { (Minhum), are martyred } \\
\text { against the enemies of } \\
\text { Allah }\end{array}$ \\
\hline 2. & $\begin{array}{l}\text { Overgeneraliza } \\
\text { tion }\end{array}$ & $\begin{array}{l}\text { The invasion of America } \\
\text { and allies of the Muslim } \\
\text { country as a form of } \\
\text { hatred and destruction } \\
\text { of the existence of } \\
\text { Muslims. }\end{array}$ \\
\hline 3. & $\begin{array}{l}\text { selective } \\
\text { abstraction } \\
\text { (Tunnel } \\
\text { Vision) }\end{array}$ & $\begin{array}{l}\text { Moral decadence, } \\
\text { politics, economic } \\
\text { slowdown, poverty and } \\
\text { crime all point to the } \\
\text { weakness of secular and } \\
\text { democratic governments } \\
\text { and the absence of } \\
\text { Islamic sharia. }\end{array}$ \\
\hline 4. & $\begin{array}{l}\text { disqualifying } \\
\text { the positive; }\end{array}$ & $\begin{array}{l}\text { Freedom of association } \\
\text { and the expression of } \\
\text { opinions in democracy } \\
\text { do not deserve to be } \\
\text { appreciated. }\end{array}$ \\
\hline 5. & $\begin{array}{l}\text { Mental } \\
\text { reading }\end{array}$ & $\begin{array}{l}\text { A violent jihad is needed } \\
\text { to defend the Islamic } \\
\text { community and create } \\
\text { peace in the world " }\end{array}$ \\
\hline 6. & $\begin{array}{l}\text { maximizatio } \\
\mathrm{n} \text { and } \\
\text { Minimizatio } \\
\mathrm{n}\end{array}$ & $\begin{array}{l}\text { A failure if you did not } \\
\text { become a martyr" }\end{array}$ \\
\hline 7. & $\begin{array}{l}\text { emotional } \\
\text { reasoning }\end{array}$ & $\begin{array}{l}\text { "Jews and Christians } \\
\text { always have intention to } \\
\text { obstruct and fight } \\
\text { Muslims to practice their } \\
\text { religion, kaffah, and such } \\
\text { intention would come } \\
\text { true someday." }\end{array}$ \\
\hline 8. & Imperative & "I must be a martyr or" \\
\hline
\end{tabular}

\begin{tabular}{|l|l|l|}
\hline & & $\begin{array}{l}\text { Shahid is much better } \\
\text { than the fate of being a } \\
\text { prisoner ". }\end{array}$ \\
\hline 9. & Labeling & $\begin{array}{l}\text { All Jews (Israelis) and } \\
\text { Christians are enemies } \\
\text { of Islam and their blood } \\
\text { is lawful. }\end{array}$ \\
\hline 1 & $\begin{array}{l}\text { Personalizati } \\
\text { on }\end{array}$ & $\begin{array}{l}\text { Moslems who only keep } \\
\text { silent and do not } \\
\text { commit "jihad" causes } \\
\text { other muslims undergo } \\
\text { the negative events }\end{array}$ \\
\hline
\end{tabular}

The similarity of terrorists and suicide attacks with individuals suffering from psychological disorders such as depression, hypomania or manic episodes, suicidal behavior, general anxiety (generalized anxiety), phobias, panic disorders, paranoid states, conversion disorders, obsessive compulsive disorder , anorexia or bulimia and hypochondria, is the presence of cognitive distortions in patients. Cognitive distortion not only causes emotional disturbances, but also affec individual behavior. Albert Ellies claims that the cognitive distortions or illogical beliefs that are continually being trusted and internalized can cause self-destructive. It means that irrational beliefs are not merely related to external factors. It is likewise associated to human thought. If a person experiences emotional disturbances, his cognitive automatically contains erroneous, irrational, and illogical sentences or meaning which are believed dogmatically, and disturb his emotions and actions and finally subordinate himself. ${ }^{24}$ Thus, we will easily understand the relationship between thoughts, emotions-feelings and behavior.

Cognitive distortions will affect changes in individual's emotions and feelings and lead

24 Albert Ellis, Rational-Emotive Psychotherapy dalam D. Arbuckle (Ed.). Counseling and Psychotherapy ( New York : McGraw-Hill, 1967), p.82 
to unexpected behavior. Therefore, cognitive therapy is proposed as a way of overcoming the problem. Through cognitive psychotherapy, distorted thinking possessed by a terrorist as a result of identification and indoctrination can be corrected and redesigned. There are two goals to achieve in the cognitive approach. First, generate clients' thoughts, interact internally or self-talk and interpret events experienced. Secondly, together with the advisor, the client collects evidences that supportsor refutes the interpretations given.

Cognitive psychotherapy applied to terrorists is still quite rare since study of cognitive psychotherapy of Aaron T Beck is much more focused on emotional disorders such as depression, panic disorder, phobias, depression and anxiety. All psychological disorder is the result of cognitive distortions in the form of irrational, unrealistic, irrational, and illogical ideas, thoughts, thoughts that are continually indoctrinated into themselves.

The cause leads terrorists with their brutal actions endanger self and others safety. It indicates cognitive distortion in the form of doctrinal values has internalized over a long period and consistenly reinforced by the cohesion of the group.

The authority of the group, even provide "spiritual sanctuary" to ensure the absorption of the ideology of the group. As the result, individuals lose their authority to control themselves. This article offers cognitive psychotherapy for terrorism cases, as it serves to restore sense of individuality which has be blend into group dynamics. Through cognitive therapy, a client is trained to increase his / her attention or awareness capacity. As ther result, he /she can think carefully and systematically about any information he or she receives. The raising awareness will cope with uncomfortable feeling, and feeling guilty because he/she refuse conformity. At the same time, he/she confidently determine how he should act and restore his belief to stop commiting acts of "jihadism" through violence.

\section{The urgency of integrating Indonesian Islamic values and cognitive psychotherapy}

The importance of integrating Indonesian Islam and psychotherapy is the approach are comprised of values of Indonesia Islam such as moderation, tolerance and the promotion of peace. According to Abdurrahman Wahid, it is the manifestation of true Islam. ${ }^{25}$

Several examples of local wisdom in indonesia respect for multiculturalism and heterogeneity, such as the Pesse (empathy), a concept of Makassar Bugis tribe, Pela gandong, a group-building culture within the ethnic and religious communities in Maluku and tepo seliro (empathy) as the concept of Javanese society. The values of local wisdom were practiced by the ancestors and manifested in the attitudes and behavior of the Indonesian people towards diversity even amid the threat of radicalism in the recent transnational Islamic movement.

The development of cognitive psychology based on Indonesia Islam has two goals. First, Implementing Abdurrahman Wahid's indigenous spirit to alleviate the inferiority of Indonesian Muslims as "secondclass Muslims" "by promoting Indonesian Islam a model for understanding diversity. Secondly, it is possible to overcome the logical fallacies or self defeating thinking of individu particularly in understanding religious doctrine as a characteristic of terrorism by organizing perceptions and thinking in a positive and rational approach. ${ }^{26}$

\footnotetext{
25 Abdurrahman Wahid., Islamku Islam Anda Islam Kita. (Jakarta : The Wahid Institute, 2006), p. 244 26 Ellies dalam Rickey L George; Therese Stridde Christiani, Theory, Methods \& Processes of Counseling and Psychotherapy (Englewood Cliffs, N.J.: Prentice-Hall, 1981), p. 89
} 
This research is a qualitative research using a mixture of literary approaches and phenomenology (mixed approach). The documentary research focused on study of books, scientific works related to the bahts almasail or ijtihad of Indonesia scholars toward Khilafah Islamiyah, Jihad and kafir (takfiri). These ijtihad based on Tasamuh's values. (tolerance), Tawasuth (moderate), Tawazun (balanced), 'Adalah (Justice) and Ukhuwah (Brotherhood) which includes ukhuwah Islamiyah (Islamic Brotherhood), Ukhuwah Wathoniyah (nationality Brotherhood), Ukhuwah basyariah (humanity brotherhood).

The phenomenological approach aims to extract data from primary sources, namely former terrorists, who are related to their views on Khilafah Islamiyah, Jihad and takfiri. The results of ijtihad are operationalized in the form of statements,which are then positioned as rational responses (self-defense) to automatic thinking of the terrorist. Such thinking will lead to irrational critic. Therefore, rational responses derived from the ijtihad of the Indonesia (archipelago) Ulama should be given as an intervention.

\section{Results and Discussion}

a. The contradictory view between terrorists perspective and Ijtihad of Ulama of Indonesia on Khilafah, Jihad and Takfiri

The results of the study showed that there were conflicting views between the perpetrators of terrorism and the ulama Nusantara ijtihad regarding the concept of khilafah, jihad and takfiri. In the context of the khilafah, the whole subject of research, namely two former terrorists, tends to consider the khilafah as a state system that must be defended, since Islam has organized all aspects, including governing the government; consequently, they argued that caliphate is the best system to overcome complexity of national problems. In contrast, Indonesia Ulamas believe that the Islamic caliphate is not a political system or a state model, but rather a concept of leadership. They support Pancasila as a political system which are most suitable with characteristic of Indonesia.

Difference of interpretation on the caliphate between the Indonesian terrorists and the Ijtihad ulama lies in ideological perspective which centralized totalitarianism towards sharia or not. While terrorists argues that implementation of sharia law can not be separated from politics, which means that it must be formalized, Indoenesia Ulama overemphasis the essence of Islamic values. If a system has accomodate Islamic principles, it has implemented practices of sharia, the formalization of sharia then is not necessary.

Second, In terrorists perspective, Jihad can be regarded as a form of physical resistance particularly the war against infidels in order to defend Islam and Muslims who have been persecuted in various parts of the world. Form of their resistance can be achieved by fighting directly or attacking strategic locations with bombs where the "infidels" gather. Through these actions, terrorists will produce a large number of victims of their enemies and providing glory to Islam. This point of view is very different from Indonesian ulama perspectives which interpret the great jihad as an effort to fight against lust, while war jihad is a type of jihad which can merelybe practiced against opponents who declare it.

In terms of qualication of target of attack, scholars and terrorists have different perspective. While terrorists have made generalizations that all infidels can be regarded as enemies, Indonesian ulama perceives infidels as enemy is for those who declared war against muslims and the objective is a self defence particularly against tyranny. The arguments of the archipelago's ulema are similar to Imam Malik, Imam Ahmad, Abu 
Hanifah, and others who refer to the essence of Al-Baqarah verse 190 as follows

" Fight in the way of Allah against those who fight against you but do not transgress, for Allah does not love transgressors". 27

In the above context, the Indonesian ulama stated that the obvious target was kafr harb. This term can be defined as an enemy as well since he was also in a state of war with the Muslims. They also states that the purpose of kind of Jihad merely to preserved the benefit of Muslims, including fighting enemy attacks. In addition, according to them, jihad is not only restrictively interpreted by murder (qital) or physical resistance, but can be broadly interpreted as an effort to build peace and orderliness of world civilization.

Third, Takfiri. Takfiri is denoting exxcomunication, which one muslim declaring another Muslim as a non-believer (kafir). In terrorist perspectives, kafr has several meaning, firstly, anyone who hinders the realization of the purpose of defending the religion of God (Allah). ${ }^{28}$

Secondly, everyone who has a different point of view, even if they are moslem or have similar religion with terrorists ${ }^{29}$ In contrast, Indonesian scholars states that radical Islamist groups behaviour to accuse other moslems as infidels since difference of opinion has eliminated the plurality as human nature. In addition, according to Indonesian scholars, takfiri refers to Imam Al-Ghazali's vision as an act that transcends borders, resembling exactly the excessive attitude of theologians at the beginning of Islam's development that regards the disagreement with theology adopted as

\footnotetext{
${ }^{27}$ Surah Al-Baqarah ayat 190 dalam Abdullah bin Zaid Al-mahmud. T.th. Al-Jihad al- Mashru' Fi al-Islam. T. Tp: T.P. : 13

${ }^{28}$ Interview with RS on 29 august 2017

${ }^{29}$ Interview with DF on 29 august 2017
}

unfaithful. ${ }^{30}$ Ironically, terrorists easily create indicators of political interests and identity as a pretext for taking takfiri against Muslim individuals or groups.

In this position, results of the ijtihad of three major theme are detailed in statements that help clients or terrorists to process more realistic information in order to replace automatic thoughts and distorted beliefs as well as replace irrational thought to rational thought through the teaching-learning process.

Based on evaluating literatures found that Ijtihad Indonesian Ulama's on the three main concepts are proven and fundamental formulation for the cognitive de-radicalization programmes.

\section{b. Procedures and techniques of cognitive psychotherapy based on Indonesian Islamic values}

Cognitive therapy is an educational process in which the therapist is active in developing good working relationships between therapists and clients (clients). This procedure is called collaborative empiricism. In this procedure, the therapist and the client collaborate in the scientific work by examining or evaluating the patient's beliefs, testing these beliefs to see whether the client's beliefs are accurate or not, and then modifying beliefs based on reality. ${ }^{31}$

The development of the model of cognitive psychotherapy based on Indonesian Islamic values is intended to be applied separately or being integrated part of development programme in correctional institution. ${ }^{32} \mathrm{~T}$

\footnotetext{
30 Imam Al-Ghazali dalam Imam Al- Baijuri, Tabqiqul Maqam ala kifayatil Awam (Surabaya: Maktabah M Bin Ahmad Nabhan Wa Audaluh: tt) p.15

31 Richard Nelson-Jones, Teori dan Praktik Konseling dan Terapi (Yogyakarta: Pustaka Pelajar, 2011), p. 582

32 Direktorat Jenderal Pemasyarakatan. Cetak Biru

Pembaharuan Pelaksanaan Sistem Pemasyarakatan.
} 
he goal of fostering prisoners of terrorism can be achieved by helping terrorists identify illogical thoughts, confront and revise illogical beliefs untill they aware their mistakes and can easily integrate into society then .

The application of the cognitive psychotherapy model to terrorists, particularly at correctional institution, can be described as follows.

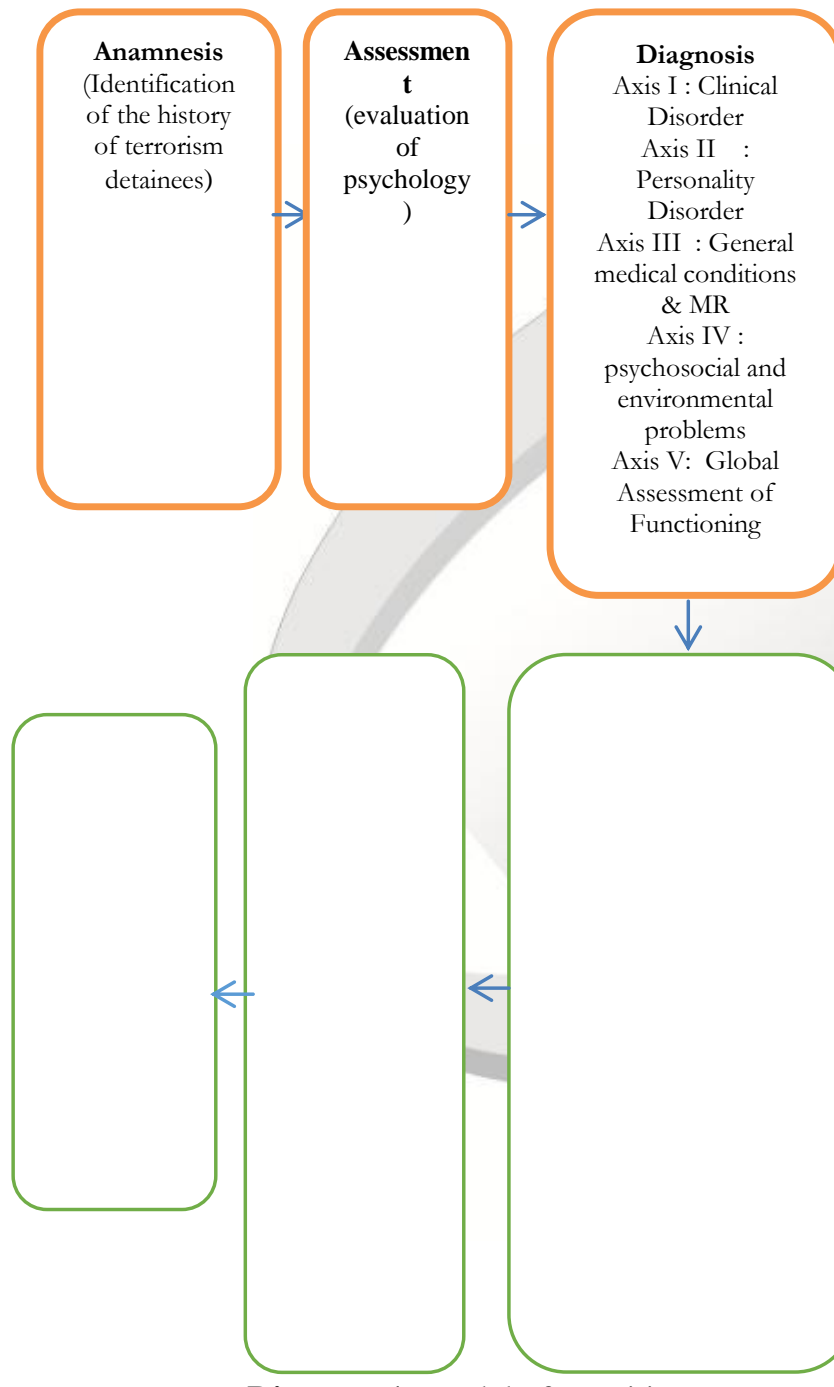

Diagram 1. Model of cognitive psychotherapy based on cognitive values in Indonesia on the actors of terrorism

The initial phase of psychotherapy can be conducted with anamnesis or collecting data about the subject's life history in order to understand the experience of the subject's life

(Jakarta : Departemen Hukum dan Hak Asasi Manusia Direktorat Jenderal Pemasyarakatan, 2008), p. 4 and gain insight into their personality. The reasons to involve in terrorist acts explored deeply, as well as their complaints and expectations .

The following step is psychological examinations or assessments that focus on commonly used thought patterns, previous stimuli, and behavioral problems. Psychological examinations use observation, interviews, life records, personality tests such as EPPS, MMPI, intelligence tests and the use of cognitive distortion scale, an instrument containing 20 elements of self-assessment to measure 10 cognitive distortions. All the cognitive distortions are evaluated in two aspects, namely interpersonal (IP) and personal achievement. ${ }^{33}$

The combination of the results of the psychological examinations is employed to classify the mental disorders (diagnoses) that based on the guidelines for the diagnosis of Mental Disorders III (PPDGJ III) or the Manual of Diagnostic Statistics (DSM IV) and the DSM IV -TR, which includes Axis I: Clinical Disorders, Axis II: Personality Disorders, Axis III: General Medical Conditions and MR, Axis IV: Psychosocial and Environmental, Axis V: Function Level. The iims of classification of the diagnosis (execution) is to determine the appropriate ype of treatment based on the condition of he client, including the type of disorder. ${ }^{34}$

Evidences on origin of terrorists' ognitive distortions as result of process of radicalization, leading cognitive psychotherapy to helps them to recognize negative thoughts and to restructure their minds and minds.

${ }^{33}$ Roger Covin, David J. A. Dozois, Avital Ogniewicz, and Pamela M. Seeds ," Measuring cognitive errors: Initial development of the Cognitive Distortions Scale (CDS)", International Journal of Cognitive Therapy, 4, 2011, p. 297.

${ }^{34}$ Vermande, M. M., Van den Bercken, J. H., \& De Bruyn, E. E. J, "Effects of diagnostic classification systems on clinical hypothesis generation", Journal of Psychopathology and Behavioral Assessment, 18, 1996, p. 49. 
During the first stage, the therapist tries to introduce negative thoughts or cognitive distortions by teaching client the kind of cognitive distortions regularly occur during treatment or asking client to identify his/her distortions during accomplishing homework. Client can apply the three-column technique as follows a) The first column describes a situation that evokes negative emotions.

b.) Column two, identify the automatic thoughts in the situation; c.) Column Three indicate what types of distortion are in these thoughts. ${ }^{35}$

The second stage, restructuring cognitive or thought by demanding the client to evaluate or rethink his/her negative thoughts through answering Socratic questions or direct questions from therapist. The direct goal of these techniques are to turn the client's closed belief system into an open system.

The questions of Socratic dialogue particularly try to help the client to aware on his/her thoughts; examining these thoughts to find cognitive distortions; replacing it with a more balanced thought; and making plans to develop new models. A statement that generates the client 's basic awareness is to ask the client: "What are you thinking right now?

Therapists prefer use questions (questioning) and avoid indoctrination and refutation. This technique is implemented in warm emotional climate and accepting. The Socratic's question and answer model develops and evaluates the client's way of thinking.

Several kind of Socratic questions as follows a.) Where do you find (antum / akhi / ukhti) this way of thinking ?, b.) Is there evidence of your beliefs? C.) Are there other ways to look at the situation? D.) What is the effect of the thinking? e.) What are the advantages and disadvantages of such thinking? f.) are you draw conclusions

35 Stephen Palmer, Windy Dryden, Counseling for Stress Problems. (London: Sage Publication, 1995). p. 263 immeaditely ? g. Do you regards this as an example of mental reading or prediction? $h$. Do you regard personally the events happens to you as small things or even have no correlation with you? ${ }^{36}$

Through Socratic dialogue, clients learn to ask questions. In the case of terrorism, clients ask his/her the automatic thoughts, even if the thoughts consistent with his/her "feelings". Clients who experience emotional disturbances due to cognitive distortions may question the validity of their own thoughts through the following questions:

a) "Where do I find this way of thinking?" b. "What evidence supports my interpretation?" c. What evidence contradicts with my interpretation? d. Is the motives that I logically atribute to the other groups is suitable with their actions" and e) Are there alternative explanations for my behavior? Through Socratic dialogue, terrorists learn to counter negative thoughts and seek other more appropriate ideas. ${ }^{37}$ The process of cognitive restructuring is illustrated in the table below.

\footnotetext{
36 Stephen Palmer, Windy Dryden, Counseling for Stress Problems. ). p. 265

${ }^{37}$ David Westbrook., Helen Kennerley., Joan Kirk, An introduction to cognitive behaviour therapy : Skills \& applications. (London : Sage Publication, 2007), p. 257.
} 


\begin{tabular}{|l}
\hline \multicolumn{4}{|c|}{ Dysfunctional Thought Records } \\
\hline Instructions: When you feel your mood is getting worse, \\
ask yourself what happened to my thought right now? and \\
directly record your mental thoughts or images in the \\
automatic mind column. Then identify the emotions, \\
feelings or moods you feel when you have these thoughts. \\
Then check whether these thoughts are realistic or accurate \\
and start developing a more rational response, with \\
alternative thoughts which are adapted to the situation. \\
$\begin{array}{c}\text { Evaluate or value how many more rational responses } \\
\text { which have changed your original thoughts and feelings. }\end{array}$ \\
\hline $\begin{array}{c}\text { Situatio } \\
\mathrm{n}\end{array}$
\end{tabular}

To create alternative answers, ask the following question:

1. What is the evidences that your (antum or akhi / ukhti) automatic thoughts are true? What is the proof that automatic thoughts are not true?

2. Is there an alternative explanation for each event or other way of looking at the situation?

3. What are the implications if your thoughts are correct? What is the worst thing in the situation? What is the most realistic thing in this situation? What could you do about it?
Table 2 . Functional thoughts notes

Source : Judith Beck, 2005

The pivotal role of Indonesian Islamic values in cognitive psychotherapy are to provide adaptive responses related to ideological themes or major problems of radical organizations such as Khilafah Islamiyah, Jihad and disbelief (takfiri) in the form of a dialogue between therapists and clients, including terrorist inmates. These three themes can be identified as cognitive distortions such as khilafah Islamiyah (selective abstraction, positive disqualification), the concept of Jihad ( mental reading / arbitrary inference, maximization and Minimization, imperative, personalization), disbelief/takfiri (polarization, generalization, emotional reasoning, , labeling).

Adaptive responses to cognitive psychotherapy based on Indonesian Islam against cognitive distortions related to khilafah Islamiyah, for example 1.) Testing the evidence of automatic thoughts of terrorist members on the failure of democracy and Pancasila, while showing the success of pancasila as a paradigm in the development of political, economic, socio-cultural and defense security in Indonesia

2.) Providing another way of looking at the situation for example (a) The absence of texts in the Qur'an that underlie the idea of an Islamic State or the urgency to establish an Islamic state, except merely limited to 
ijtihadiyah or interpretive. b.) Islamic sharia, can be implemented without formalizing Islamic state . Indonesian Islam tend to prioritize the substance of sharia values in society rather than formalizing institutions. ${ }^{38}$ Indonesian Islamic values briefly place Pancasila as the reflector of Maqashid alShari'ah (common good). 3.) If your mind considers pancasila and democracy as a cause of national decadence is true, what are the implications for you? What is the worst thing of the situation? What are the most realistic things you can see on your daily life? What could you do?

The third question attempts to explore the patterns and assumptions underlying the emergence of cognitive distortions among terrorist inmates or to focus on the personal significance of an event. In the above example, the basic assumption is: "If I allow the NKRI system based on Pancasila to continue and I still do not attempts to promote caliphate, I am a useless person and the scheme is: "I am a useless person" The assumptions and basic schemas are then discussed with the client or the terrorist. If they agree, following steps is the psychotherapist and the client continue to modify client assumptions and basic schemas . For example, stating that "the maintenance of republic of Indonesia on the basis of the Pancasila and the 1945 Constitution shows the person tries to provide much benefits for other people without questioning the diverse background. ${ }^{39}$

The process of modifying such assumptions can adopt Padesky and Greenberger's modification scheme, which includes: (a) Writing his or her current beliefs , followed by writing down the list of experience that misdoubt the accuracy and

38 Abdurrahman Wahid, Musuh dalam Selimut". Ilusi Negara Islam. Ekspansi Gerakan Islam Transnasional di Indonesia. (Jakarta: The Wahid Institute, 2009), p. 257

39 Abdurrahman Wahid, Musuh dalam Selimut". Ilusi Negara Islam. Ekspansi Gerakan Islam Transnasional di Indonesia, p. 18 validity of the beliefs (not $100 \%$ correct). (b) Write new belief which more realistic and write several experiences to support the new belief. (c) regularly evaluate your confidence to this new belief. The whole process can be done separately or integrated into the dysfunctional record table of thought . ${ }^{40}$

Adaptive responses of cognitive psychotherapy based on Indonesian Islamic regarding to to jihad as following steps 1.) Testing evidence of automatic thoughts of terrorist members on war jihad or qital and martyrdom as a form of defense against the Muslims, establishing peace in the world and rewarding paradise. At the same time, show proof that these automatic thoughts are not true, for example jihad in the defense of Muslims against the superpower and its allies, while their jihad that is executed is qital (war) in Indonesia, in which does not is not a war zone (dar al harb).

How to create world peace while they used violence or war (qital) especially for civil society. For example, the activities of "jihad" or suicidal martyrdom, as in Pakistan, Turkey, Syria, Iraq and Indonesia, result in many victims among Muslims rather than among non-Muslims. How could the kind of jihad be rewarded by heaven while its effects eliminate the lives of innocent people? How to distinguish such jihad from suicide?

2.) Provide alternative way to evaluate the situation for example: a) The defense of Muslims or the establishment of peace in the world is much more effective through a system or path of diplomacy than by the individual struggle. b) Jihad always changes according to its context and environment (muqtada al-bal wal mahal). In Indonesian context, the supreme of jihad is positive efforts to compete with the developed western in various fields .C.) Jihad

40 Christine A. Padesky \& Dennis Greenberger, Clinician's Guide to Mind Over Mood. (New York : Guilford, 1995), p. 327 
as a tool of creating world peace could be implemented as long as suitable with rahmatan lil'alamin mission which prioritizing the principles of tasawub (tolerance), tawassuth (moderation) and tawazun (balanced) which suitable with the objective conditions of pluralism.

3.) If your mind is that jihad with war is a goal and an obligation for every Muslim. What are the implications for you? Which worst condition will occurs on this situation? What is the worst thing in the situation? What is the most realistic thing about the condition? What could you do about it? Question number three produces the basic schema and hypotheses that are supposed to be, "If I am not a martyr, then my struggle is useless, I am useless, I can not fulfill the commandments of God. the scheme is "I am a useless person, i am worthless person, $i$ have failed .

The basic assumptions and systems are further modified by stating that "not being martyred is not the end of everything". "You can also do many good things in different ways." The application of God's teachings is not only mortal, but it also drives the progress of Muslims in various aspects of life. The modification efforts sustainably applied untill dysfunctional tendencies which criticize and blame self could be overcome.

Adaptive responses or answers to cognitive distortions related to takfiri, can be implemented by following these procedures 1.) Testing the evidence of automatic thoughts that, outside of their group such as Jews, Christians and even Muslims, are unfaithful and intend to destroy Muslims (in groups) while showing evidence of the invalidity of these automatic thoughts. For example, showing that dissent in Islam is a blessing. Accusing infidels without clear and precise evidence in the texts of Al-Quran and AlHadith are prohibited acts. On the contrary, the one who accuses others can be regarded as an infidel. Regarding the mission of the infidels to destruct Muslims can be countered by exemplifying the equal rights and obligations between Muslims and non-muslims in countries accused of being infidels as well as providing evidence harmonious and tolerance situation in religous diversity in Indonesia society.

2.) Providing another way to evaluate situation which regarded as problemati issue. For example, a.) Truly Islam is ummatan wasatha, a moderate people as Ahlu sunnah wal Jamaah b.) Making Introspection and selfimprovement efforts which are related to what extent client perceives his/her self as a true Muslim. c.) Shows that takfiri has an impact on the breakdown of relations among Muslims and means that the subject has committed acts which are hated by Allah.

3. If your mind that Muslims are accused of being unfaithful as well as Christians and Jews threaten the existence of your group, what are the implications for you? What is the worst thing in the situation? What is the most realistic thing about the condition? what could you do about it? The third question produces basic schema and assumption: "If I do not regard them as enemies and I'm not aware of the intentions of infidels, these mean that I do not work well as a member, therefore I am a useless person."

The basic assumptions and schema of takfiri themes are also modified by stating that the requirement to accuse others as kafr (infidels) and continuous suspicion to others or " kafr" " intention hurted and weakened your self. "You are not useless as long as you can appreciate your own perspective (not accuse others as infidels). In short, these processes could be a effective method to encounter dysfunctional thinking which critisizes and blames self.

The last steps of the procuderues is to provide routinely homework to record dysfunctional thinking. This method is a form of evaluation learning toward terrorists' 
cognitive distortions. The process of cognitive restructuring by recording functional thinking, using the same pattern of work that is systematically applied by terrorist groups against its members, which includes selfreplicating autosuggestion processes in the form of spontaneous verbalizations. The difference is that intensive indoctrination of terrorist groups contains cognitive distortions and has an impact on self-destruction, while cognitive psycho-therapy contains rational beliefs aimed at improving the psychological well-being of convicted terrorists.

Following routine of homework encourage terrorist inmates to focus on their automatic thoughts and to take responsibility to help themselves. This measures is a key element of prevention and mitigation to the effects of intensive indoctrination of radical ideologies. Cognitive restructuring effort enables actors to modify their interpretations and perceptions of situations, events and problems in order to avoid non-positive emotions, such as anger, sadness, frustration and guilt, and to produce healthier and adaptive behavioral responses particularly avoiding terrorism actions. The follow-up model for developing cognitive therapy based on Islamic values in Indonesia requires sustainability efforts to evaluate assessment of therapies, diagnostic and competency of the therapist.

\section{Conclusion}

Results of phenomenological studies and literature from the main sources which taken from interview with former terrorists and analyse result of bahtsul masail which taken from various Indonesian ulama literature as follows. Firstly, there are conflicting differences between the views of the terrorists and ijtihad of Indonesia (archipelago) Ulama (scholar) regarding khilafah, jihad and takfiri.
Secondly, the model of cognitive psychotherapy based on Indonesian Islamic values was developed after verification of the analysis content. The excellence of the therapy is not only since based on Indonesian Islamic values, but also applying collaborative empiricism procedures that place clients to involve in an active collaborative working relationship. As the result, Indonesian Islamic values could be intentionally internalized by terrorists themselves. This model would be effective in changing the destructive thinking schemata of terrorists.

The weaknesses and limitations founded of this model requires ongoing scientific studies, including re-examination of conceptual models, treatment methods, protocols to deal with terrorism-destructive thinking and behavioral, and testing the effectiveness of these modules / techniques. as an interventions for de-radicalization programs by undertaking several experimental studies.

- Finally, the political will of the government, particularly national agency for combating terrorism (BNPT to encourage the development of this model as well as building training centers of the cognitive terapy on which based value of Indonesia Islam in several regions of the country untill it can serve as a model for dealing with terrorism cases at the national and global levels.

\section{References}

\section{Text Book}

Beck, Aaroon T., dan Marjorie E. Weishaar . Cognitive Therapy; dalam Raymond J. Corsini dan Danny Wedding, Current Psychoterapies, Fourth Edition.F.E. Peacock (Illinois : Peacock, 1989)

Beck, Judith .S (2005). Cognitive therapy :Basics and beyond. New York: Guilford Press. 
Burns, David, Terapi kognitif. Pendekatan baru bagi penanganan depresi (Jakarta: Erlangga, 1988)

De la corte, L, La logica del terorismo.( Madrid : Alianza, 2006)

Direktorat Jenderal Pemasyarakatan (2008). Cetak Biru Pembaharuan Pelaksanaan Sistem Pemasyarakatan. (Jakarta : Departemen Hukum dan Hak Asasi Manusia Direktorat Jenderal Pemasyarakatan, 2006)

Ellis, Albert, Rational-Emotive Psychotherapy"; dalam D. Arbuckle (Ed.). Counseling and Psychotherapy. ( New York : McGrawHill, 1967)

Ellis, Albert, Rational-Emotive Theory", dalam A. Burton (Ed.), Operational Theories of Personality, (New York: Brunner/Mazel, 1974)

George, Rickey L and Therese Stridde. Cristiani.. Theory, Methods \& Processes of Counseling and Psychotherapy (Englewood Cliffs, N.J.: Prentice-Hall, 1981),

Hurlock., Elizabeth. B.,Psikologi Perkembangan. Suatu pendekatan sepanjang rentang kehidupan, Edisi 5. (Jakarta : Erlangga, 1980)

Imam Al- Baijuri, Tahqiqul Maqam ala kifayatil Awam (Surabaya: Maktabah M Bin Ahmad Nabhan Wa Audaluh: tt)

Lezak, Muriel. Deutsch. (1995). Neuropsychological assessment. 3rd ed. New York : Oxford University Press

Nelson-Jones, R, Teori dan Praktik Konseling dan Terapi (Yogyakarta: Pustaka Pelajar, 2011).

Padesky, C.A. dan Greenberger, D, Clinician's Guide to Mind Over Mood. (New York : Guilford, 1995)
Palmer, Stephen. \& Dryden, Windy, Counseling for Stress Problems. (London: Sage Publication, 1995)

Sageman, Marc, Understanding terror networks. (Philadelphia: University of Pennsylvania Press, 2004).

Silber, Mitchell. D., \& Bhatt, Arvin, Radicalisation in the West : The Homegrown Threat : (The New York City Police Department, 2007)

Wahid, Abdurrahman, Islamku Islam Anda Islam Kita. (Jakarta : The Wahid Institute, 2006)

Wahid, Abdurrahman, Musuh dalam Selimut. Ilusi Negara Islam. Ekspansi Gerakan Islam Transnasional di Indonesia. (Jakarta: The Wahid Institute, 2009)

Westbrook, David., Kennerley, Helen. \& Kirk, Joan, An introduction to cognitive behaviour therapy: Skills \& applications. (London : Sage Publication, 2007)

\section{Journals}

Berkowitz, Leonard. " Frustration- aggression hypothesis : Examination and reformulation", Psychological Bulletin, 106, 1989 h. 59

Berman, Sheri, "Islamism, Revolution, and Civil Society, Perspectives on Politics, 1, American Political Science Association, 2003, h. 18

Bryant, Ernest.T., Monte .L. Scott, Charles J.Golden, and Christopher .D. Tori. "Neuropsychological deficits, learning disability, and violent behavior", Journal of Consulting and Clinical Psychology 52:323, 1984, h. 4.

Covin, Roger., Dozois, David., Ogniewicz, Avital., \& Seeds, Pamela. M. (2011). Measuring cognitive errors: Initial 
development of the Cognitive Distortions Scale (CDS). International Journal of Cognitive Therapy, 4, 297-322.

Milla Noor Milla. \& Faturochman. Pembentukan identitas mujahid global pada terpidana kasus terorisme di Indonesia. Jurnal Psikologi Indonesia, Vol VI, No.2, 2009, 82

Vermande, M.M., Van den Bercken, J.H., \& De Bruyn, E.E, "Effects of diagnostic classification systems on clinical hypothesis generation. Journal of Psychopathology and Behavioral Assessment, 18,1996, h. 49.

Victoroff, Jeff., "The mind of the terrorist: A review and crtitique of psychological approaches", Journal of conflict Resolution, 49, 2005, h. 3.

\section{Article in Media}

Hassan., Nasra. An arsenal of believers : Talking to the " human bombs." The New Yorker 77:36, 2001

Sim, Susan. \& Ismail Noor. Huda , “ Predicting terrorist recidivism in Indonesia's prisons. The Brooking Press. 2016, january 28. Para.3 http://www.brookings.edu

Storr, Anthony.. The threat of man human agression. The Penguin Press, 1968, July 13 Diambil dari http://www. thetablet.co.uk

\section{Interview}

DF, Wawancara Pribadi, Selasa 29 Agustus 2017.

RS, Wawancara Pribadi, Selasa 29 Agustus 2017. 